\title{
Sheep grazing efficiency and selectivity on Oregon hill pasture
}

\author{
ELTOM ALI AND STEVEN H. SHARROW
}

\begin{abstract}
Authors are former graduate student and professor, Department of Rangeland Resources, Oregon State University, Corvallis 97331. Dr. Ali is presently lecturer, University of Khartoum, Sudan.
\end{abstract}

\begin{abstract}
Grazing trials were conducted during early and late spring of 1988 and 1989 to evaluate the impact of sheep grazing duration and stocking density on grazing efficiency and forage selectivity in tall fescue (Festuca arundinacea Schreb.)-subclover (Trifolium

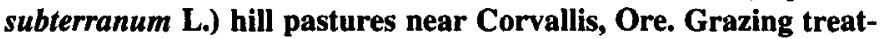
ments were 2,6 , and 10 days duration with corresponding stocking densities $380,130,78$, and $1,390,460$, and 280 ewes/ha during early and late spring trials each year, respectively.

Grazing efficiency was generally greater $(P<0.05)$ for the low density/longer duration (10-day) than for higher density/shorter duration (2-day) treatments. Greater grazing efficiency as duration increased largely reflected higher rates of intake rather than lower levels of non-consumptive forage destruction. Stocking density within a constant grazing duration (2 days) had little effect on grazing efficiency.

Within the 10 day grazing treatment, grazing efficiency was highest during the last $\mathbf{4}$ days and lowest during the first $\mathbf{2}$ days $(P<0.05)$. Although short duration/high density grazing is considered to be non-selective, sheep were equally or more selective under very short duration/very high density compared to longer duration/lower density treatments in this study. These results suggest that the very short duration with very high stocking density was not an attractive management option since grazing efficiency was low and sheep were more selective
\end{abstract}

Key Words: short-duration grazing, grazing management, preference index, Festuca arundinacea, Trifolium subterranium

A common goal of grazing management is to increase livestock production per unit area of land while maintaining or improving the forage resource (Walker 1984). Production can be increased by increasing the amount of digestible forage produced and the efficiency by which forage is harvested. For a set amount of forage, a high proportion of plant energy and other nutrients will be channeled into the animal production cycle and grazing animal production will increase as efficiency of grazing increases (Vallentine, 1990). It has been suggested (Heitschmidt and Walker, 1983; Stoltz and Danckwerts 1990; Sharrow 1983) that increasing animal density while shortening grazing duration (i.e. rotational grazing) will result in more uniform grazing of pastures as livestock are forced to search

\footnotetext{
Contribution from Oregon Agricultural Experimental Station, Corvallis, Tech. Paper Number 10,057

Manuscript accepted 30 Apr. 1994.
}

all areas of the pasture for forage and to consume less favored plants to a greater extent. More uniform grazing. therefore, is often associated with increased efficiency of forage harvest and reduced dietary selectivity of livestock.

In western Oregon hill pastures, where sheep production is largely forage-based, introduction of more efficienct methods to produce forage and convert it into salable animal product could greatly increase productivity. Considerable information is known about how to produce forage, but much less is known about the factors that influence grazing efficiency and forage selectivity. The purpose of this study was to quantify the impacts of grazing duration and stocking density on grazing efficiency and dietary selectivity of sheep.

\section{Materials and Methods}

The study was conducted on the Oregon Agricultural Experimental Station Wilson tract (Latitude $44 \mathrm{~N}$, longitude $123 \mathrm{~W}$ ), approximately 5.5 kilometers northwest of Corvallis, Ore. The rolling hill pastures on the Wilson tract have approximately $9 \%$ west facing slope. Elevation is approximately 190 meters above sea level. Climate of the area is maritime, with rainy winters and warm, dry summers. Average annual precipitation is approximately $900 \mathrm{~mm}$ (NOAA 1988,1989 ), about $80 \%$ of which falls as rain during October through March each year. Soil is a Philomath silty clay (Vertic Hyploxeroll; Soil Conservation Service 1975). The study pastures were composed of approximately $60 \%$ tall fescue (Festuca arundinacea Schreb.) and $20 \%$ subclover (Trifolium subterraneum L.) with $20 \%$ of perennial ryegrass (Lolium perenne L.), white clover (Trifolium repens), and other annual and perennial grasses by weight.

Grazing trials were conducted during early (April) and late (June) spring in 1988, and 1989. Dry ewes were randomly allocated each year for each trial to the experimental pastures from a flock maintained by the Animal Science Department, Oregon State University. The sheep were allowed to graze similar pastures, adjacent to the experimental pasture, 3 to 5 days prior to the start of each grazing trial.

Grazing duration treatments applied in each trial were 2,6 , and 10 days. Forage allowance and herd size were held constant within trials while changing grazing duration and stocking density by manipulating paddock size (Table 1). Paddock size was designed to supply a forage allowance of $2.5 \mathrm{~kg}$ dry matter/ewe/day with a $400 \mathrm{~kg} / \mathrm{ha}$ residue in early trials and $800 \mathrm{~kg} / \mathrm{ha}$ residue remaining after grazing in late trials. Levels of stocking density were higher in the late trials due to high initial forage standing crop. Stocking densities are designated in the text as high, medium, and low for the 2, 6, and, 10- day 
Table 1. Daily forage allowance, number of ewes per paddock, size of paddock, stocking density and stocking rate under three grazing durations during early and late trials of 1988 and 1989.

\begin{tabular}{lcccccc}
\hline & \multicolumn{1}{c}{ Early } & & & Late & \\
\cline { 2 - 7 } Grazing duration (days) & 2 & 6 & 10 & 2 & 6 & 10 \\
$\begin{array}{l}\text { Daily forage allowance } \\
\text { (kg DM/ewe/day) }\end{array}$ & 2.5 & 2.5 & 2.5 & 2.5 & 2.5 & 2.5 \\
Number of ewes/paddock & 7 & 7 & 7 & 10 & 10 & 10 \\
Paddock size (m) & $23 \times 8$ & $23 \times 24$ & $23 \times 40$ & $9 \times 8$ & $9 \times 24$ & $9 \times 40$ \\
Stock density (ewes/ha) & 380 & 126 & 76 & 1390 & 463 & 278 \\
Stocking rate (ewe days/ha) & 760 & 756 & 760 & 2780 & 2778 & 2780 \\
\hline
\end{tabular}

duration treatments, respectively. Treatments were replicated 4 times in a randomized complete block design.

Effects of stocking density within a constant duration were examined by comparing data collected during the initial 2 days of each grazing treatment. The 10-day duration treatment was divided into 3 stages during grazing to determine the pattern of intake within duration under a constant stocking density. These stages were the first 2 days (A), next 4 days (B) and the last 4 days (C).

\section{Measurements}

Forage mass before and after grazing was determined by harvesting all live herbage and litter within 12 randomly selected $0.1^{2}$ rectangular quadrates to ground level in all paddocks. Twelve additional phytomass samples were clipped at the end of the first 2 and 6 days of grazing in 10-day paddocks. The forage samples were dried in an oven at $50^{\circ} \mathrm{C}$ for 48 hours and dry weights were recorded. Average daily forage intake ( $\mathrm{kg} / \mathrm{ewe} /$ day) was calculated as the difference between pre-grazing and post-grazing forage mass (green+litter) divided by the stocking rate (stocking density $x$ duration). Post-grazing forage mass was adjusted for the amount of growth during each period using estimates of pasture growth derived from clipping 12 quadrants/block in adjacent ungrazed pasture at the beginning and the end of each trial period.

Four samples were selected randomly from the 12 samples clipped per paddock in each sampling date. These samples were hand-sorted into tall fescue, subclover, others (grasses and forbs), and litter (old and new). The average weight of each component in the 4 samples was recorded to estimate their percentages in pasture before and after grazing. The weight of each component in pasture was estimated by multiplying the percent of the forage component by the average weight obtained from the 12 samples. The dry weight of tall fescue, subclover and other species, collectively represent the green forage dry matter in pastures before and after grazing. Green forage dry matter after grazing, in each grazing event, was subtracted from green forage dry matter before grazing to estimate the amount of green forage disappearance (consumed and destroyed by sheep). Forage covered by manure along with that transferred from the green forage to litter categories (primarily by trampling) was considered destroyed. Grazing efficiency (GE) for the purpose of this study is defined as the ratio of green forage consumed by animals to the amount consumed plus that destroyed by the grazing animals (Stuth et al. 1981).

$$
\text { Grazing Efficiency }=\frac{\text { Forage intake }}{\text { Forage disappearance }} \times 100
$$

Sheep preference for tall fescue, subclover, and other species (as a group) were evaluated under different grazing duration treatments with a relative preference index (Van Dyne and Heady, 1965):

Relative Preference Index $=\frac{\% \text { forage species in diet }}{\% \text { forage species in pasture }}$
Confidence Intervals were constructed for Relative Preference Index to aid in their interpretation (Hobbs and Bowden, 1982). Index values were interpreted as follows: (1) Relative Preference Indexes whose lower limit of the $95 \%$ Confidence Interval exceeded 1.0 indicated preference, (2) Relative Preference Indexes whose upper limit of the $95 \%$ Confidence Interval was less than 1.0 indicated avoidance (3) Relative Preference Indexes whose 95\% Confidence Intcrval included 1.0 indicated random selection.

During the early trial each year, the total number of tall fescue tillers and the percentage of them grazed were recorded for each of twenty $80 \mathrm{~cm}^{2}$ randomly located quadrats at the end of the grazing period to estimate the evenness of grazing.

\section{Statistical Analysis}

Data for each trial were analyzed as a randomized complete block design with paddocks as replications. Means of significant $(P<0.05)$ treatment differences, were separated using Student-Newman-Keul's procedure (Steel and Torrie, 1980).

\section{Results and Discussion}

A critical factor affecting animal production is the amount of forage dry matter produced and the efficiency with which dry matter is converted into salable animal products. For the purpose of this study, grazing efficiency is based on relating average daily intake (kg/ewe/day) to green forage disappearance (kg/ewe/day). Grazing efficiency was higher $(P<0.05)$ under 10-day duration than 2-day duration treatments in the early trial of 1988 and early, and late trials of 1989 (Table 2). Grazing efficiency followed a similar numerical trend in the 1988 late trial, but differences lacked statistical signifi-

Table 2. Average daily intake (ADI), forage disappearance (DISAP), forage destroyed (DEST) and grazing efficiency (GE) by sheep under 3 levels of grazing duration during early spring (April-May) and late spring (June-July) in 1988 and 1989.

\begin{tabular}{|c|c|c|c|c|c|c|c|c|}
\hline \multirow[t]{2}{*}{$\begin{array}{l}\text { Duration } \\
\text { (days) }\end{array}$} & \multicolumn{4}{|c|}{ Early } & \multicolumn{4}{|c|}{ Late } \\
\hline & $A D I$ & DISAP & $D E S T$ & $\overline{G E}$ & $\overline{A D I}$ & DISAF & $D E S T$ & $\overline{G E}$ \\
\hline 1988 & \multicolumn{4}{|c|}{ - - - (kg/ewe/day) - - (\%) } & \multicolumn{3}{|c|}{ - - ( kg/ewe/day) - - } & $(\%)$ \\
\hline 2 & $0.63 b$ & $1.32 c$ & $0.69 \mathrm{a}$ & $48 b$ & $0.76 \mathrm{~b}$ & $0.19 \mathrm{c}$ & $0.43 a$ & $64 a$ \\
\hline 6 & $1.37 \mathrm{a}$ & $2.08 \mathrm{~b}$ & $0.71 \mathrm{a}$ & $66 a$ & $1.19 \mathrm{a}$ & $1.76 \mathrm{~b}$ & $0.57 \mathrm{a}$ & $68 \mathrm{a}$ \\
\hline 10 & $1.83 \mathrm{a}$ & $2.55 \mathrm{a}$ & $0.72 \mathrm{a}$ & $72 \mathrm{a}$ & $1.39 \mathrm{a}$ & $2.03 a$ & $0.64 a$ & $69 a$ \\
\hline SE & 0.17 & 0.16 & 0.07 & 5 & 0.10 & 0.11 & 0.04 & 2 \\
\hline \multicolumn{9}{|l|}{$\underline{1989}$} \\
\hline 2 & $0.62 c$ & $1.03 \mathrm{a}$ & $0.41 \mathrm{a}$ & $60 \mathrm{~b}$ & $0.81 \mathrm{~b}$ & $1.09 b$ & $0.28 \mathrm{a}$ & $74 \mathrm{~b}$ \\
\hline 6 & $1.72 \mathrm{~b}$ & $2.32 b$ & $0.60 \mathrm{a}$ & $74 a$ & $1.62 \mathrm{a}$ & $1.96 \mathrm{a}$ & $0.34 \mathrm{a}$ & $83 a$ \\
\hline 10 & $2.44 \mathrm{a}$ & $3.10 \mathrm{c}$ & $0.66 \mathrm{a}$ & $79 a$ & $1.72 \mathrm{a}$ & $2.00 \mathrm{a}$ & $0.28 \mathrm{a}$ & $86 a$ \\
\hline SE & 0.23 & 0.26 & 0.05 & 3 & 0.13 & 0.12 & & 2 \\
\hline
\end{tabular}

Means within a column and year not sharing a common letter differ $(P<.05$, using Student-Newman-Keuls test). SE is standard error. 
Table 3. Average daily intake (ADI), forage disappearance (DISAP), forage destroyed (DEST) and grazing efficiency (GE) by sheep under 3 levels of stocking densities in 2 days grazing during early spring (April-May) and late spring (June-July) in 1988-1989.

\begin{tabular}{|c|c|c|c|c|c|c|c|c|}
\hline \multirow{2}{*}{$\begin{array}{l}\text { Density } \\
\text { levels }\end{array}$} & \multicolumn{4}{|c|}{ Early } & \multicolumn{4}{|c|}{ Late } \\
\hline & $A D I$ & DISAP & DEST & $G E$ & $A D I$ & DISAP & $D E S T$ & $G E$ \\
\hline 1988 & \multicolumn{4}{|c|}{$\ldots-(\mathrm{kg} / \mathrm{ewe} /$ day $) \ldots(\%)$} & \multicolumn{3}{|c|}{$\ldots-(\mathrm{kg} / \mathrm{ewe} /$ day $)-\ldots$} & $(\%)$ \\
\hline$\overline{\text { High }}$ & $0.63 b$ & $1.32 \mathrm{~b}$ & $0.69 \mathrm{~b}$ & $48 a$ & $0.76 a$ & $1.19 \mathrm{~b}$ & $0.43 b$ & $64 a$ \\
\hline Medium & $1.87 \mathrm{a}$ & $3.14 \mathrm{a}$ & $1.27 \mathrm{a}$ & $59 a$ & $1.44 \mathrm{a}$ & $1.94 \mathrm{ab}$ & $0.50 \mathrm{~b}$ & $74 a$ \\
\hline Low & $1.73 a$ & $3.59 \mathrm{a}$ & $1.86 a$ & $48 \mathrm{a}$ & $1.05 \mathrm{a}$ & $2.64 a$ & $1.59 \mathrm{a}$ & $40 \mathrm{~b}$ \\
\hline SE & 0.20 & 0.34 & 0.18 & 3 & 0.18 & 0.23 & 0.17 & 6 \\
\hline \multicolumn{9}{|l|}{1989} \\
\hline High & $0.62 c$ & $1.03 \mathrm{c}$ & $0.41 b$ & $60 a$ & $0.81 \mathrm{~b}$ & $1.09 \mathrm{~b}$ & $0.28 \mathrm{a}$ & $75 a$ \\
\hline Medium & $1.45 b$ & $2.49 b$ & $1.04 b$ & $58 \mathrm{a}$ & $1.84 \mathrm{a}$ & $2.30 \mathrm{a}$ & $0.46 \mathrm{a}$ & $80 \mathrm{a}$ \\
\hline Low & $2.39 \mathrm{a}$ & $4.23 \mathrm{a}$ & $1.84 \mathrm{a}$ & $57 \mathrm{a}$ & $2.03 \mathrm{a}$ & $2.48 \mathrm{a}$ & $0.45 \mathrm{a}$ & $82 a$ \\
\hline SE & 0.27 & 0.46 & 0.21 & 2 & 0.18 & 0.20 & 0.03 & 2 \\
\hline
\end{tabular}

Means within a column andyear not sharing common letter differ $(P<.05$, using StudentNewman-Keuls test). SE is standard error.

cance. Average daily forage disappearance in all trials was higher under the 10-day duration compared to the 2-day duration. Increased forage disappearance as grazing duration increased was also reported by Sheath (1983). The amount of forage destroyed by grazing animals was similar $(P>0.05)$ under all grazing duration treatments. These results suggest that the lower grazing efficiency under 2-day duration compared to 10-day duration is largely due to lower average daily intake rather than to higher forage destruction.

The effect of stocking density within a constant grazing duration on grazing efficiency was estimated during the first 2 days in all grazing treatments. No differences in grazing efficiency $(P>0.05)$ were detected during the early trial of 1988 and both trials of 1989 (Table 3). Average daily forage disappearance per animal in all trials increased $(P<0.05)$ as stocking density decreased. Similar results were reported by other authors (Kothmann and Allison 1979 Stuth and Kirby 1981; Allison et al. 1982). The amount of forage destroyed by each ewe during the first 2 days of grazing was higher $(P<0.05)$ under the low density treatment compared to other treatments during all trials of 1988 and the early trial of 1989 (Table 3). During the late trial of 1989, no difference was detected in forage destroyed between treatments $(P>0.05)$, but numerically, the low density treatment had more forage destroyed than did the high density treatment. Similar grazing efficiencies under different densities of livestock during the initial 2 days of our trials reflects the high amount of forage destroyed under the low density treatment which offset the effect of

Table 4. Average daily intake (ADI), forage disappearance (DISAP), forage destroyed (DEST) and grazing efficiency (GE) by sheep under three stages of grazing duration within the 10-day duration during early spring (April-May) and late spring (June-July) in 1988 and 1989.

\begin{tabular}{|c|c|c|c|c|c|c|c|c|}
\hline \multirow[b]{2}{*}{ Stages 1} & \multicolumn{4}{|c|}{ Early } & \multicolumn{4}{|c|}{ Late } \\
\hline & $\overline{A D I}$ & DISAP & $D E S T$ & $G E$ & $\overline{A D I}$ & DISAP & $D E S T$ & $G E$ \\
\hline 1988 & \multicolumn{4}{|c|}{. - (kg/ewe/day $)$ - . (\%) } & \multicolumn{3}{|c|}{ - - -( kg/ewe/day $) \ldots$} & (\%) \\
\hline $\bar{A}$ & $1.73 \mathrm{a}$ & $3.46 \mathrm{a}$ & $1.73 \mathrm{a}$ & $50 \mathrm{~b}$ & $1.05 \mathrm{a}$ & $2.52 \mathrm{a}$ & $1.47 \mathrm{a}$ & $42 b$ \\
\hline B & $1.87 \mathrm{a}$ & $2.22 b$ & $0.35 b$ & $84 a$ & $1.17 \mathrm{a}$ & $1.89 a$ & $0.72 b$ & $62 \mathrm{~b}$ \\
\hline C & $1.84 \mathrm{a}$ & $2.44 \mathrm{~b}$ & $0.60 \mathrm{~b}$ & $75 a$ & $1.79 \mathrm{a}$ & $2.02 \mathrm{a}$ & $0.23 b$ & $89 a$ \\
\hline SE & 0.11 & 0.20 & 0.20 & 5 & 0.17 & 0.13 & 0.18 & 7 \\
\hline \multicolumn{9}{|l|}{1989} \\
\hline $\mathbf{A}$ & $2.39 \mathrm{a}$ & $3.95 \mathrm{a}$ & $1.56 \mathrm{a}$ & $61 b$ & $2.03 a$ & $3.08 \mathrm{a}$ & $1.05 \mathrm{a}$ & $66 b$ \\
\hline B & $2.96 \mathrm{a}$ & $3.23 \mathrm{a}$ & $0.27 b$ & $92 a$ & $1.92 \mathrm{a}$ & $1.95 b$ & $0.03 b$ & 98a \\
\hline C & $1.96 \mathrm{a}$ & $2.41 \mathrm{~b}$ & $0.45 b$ & $81 a$ & $1.38 \mathrm{a}$ & $1.45 b$ & $0.07 \mathrm{~b}$ & $95 \mathrm{a}$ \\
\hline SE & 0.21 & 0.26 & 0.19 & 5 & 0.13 & 0.24 & 0.16 & 5 \\
\hline
\end{tabular}

Means within a column and year not sharing a common letter differ $(P<.05$, using Student-Keuls test). SE is standard error.

'Stage within the 10-day duration is designated by $A=$ first $B=$ next 4 days; $C=$ last 4 days.
Table 5. Percent of tillers grazed under 3 levels of grazing duration (days) by sheep during early spring (April-May) in 1988 and 1989.

\begin{tabular}{|c|c|c|c|}
\hline \multirow[b]{3}{*}{ Duration } & \multicolumn{2}{|c|}{ Years } & \multirow[b]{3}{*}{$\overline{\mathbf{x}}$} \\
\hline & \multicolumn{2}{|c|}{ 2-years } & \\
\hline & 1988 & 1989 & \\
\hline Days & \multicolumn{3}{|c|}{ 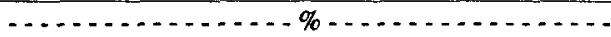 } \\
\hline 2 & $78.0 \mathrm{~b}$ & $84.0 \mathrm{~b}$ & $81.0 \mathrm{~b}$ \\
\hline 6 & $94.5 \mathrm{a}$ & $95.8 \mathrm{a}$ & $95.1 \mathrm{a}$ \\
\hline 10 & $95.3 \mathrm{a}$ & $95.5 \mathrm{a}$ & $95.3 \mathrm{a}$ \\
\hline SE & 2.7 & 2.0 & \\
\hline
\end{tabular}

Means within a column not sharing a common letter differ $(P<.05$, using StudentNewman-Keul test). SE is standard error.

higher forage intake of that treatment. At high stocking density, most of the forage disappearance was eaten by the animal. In the late trial of 1988, the lower grazing efficiency under low density treatment was largely due to the increase in forage disappearance since average daily intake was similar under all stocking density treatments. Similar results were reported by Allison et al. (1982).

Within the 10-day treatment, grazing efficiency was lower $(P<0.05)$ during the first 2 days compared to the next 4 days and last 4 days (Table 4$)$. Rate of forage disappearance was highest $(P<0.05)$ during the first 2 days. Higher forage disappearance during the early stages of grazing may be due to an initially high forage allowance (Allison and Kothmann 1979) or to establishment of trails, bedding areas and other habitual use areas by ewes. The decline in the amount of forage destroyed by grazing animals during the later stages of the 10-day duration may result from animals confining their activities to the habitual use areas selected during the early stages. This resulted in the highest grazing efficiency during the last 4 days.

Increased grazing efficiency may be achieved by applying more uniform frequency and intensity of grazing to the sward (Hinnat and Kothmann, 1986). Proportions of tillers grazed is an indication of the amount of forage removed, the evenness of grazing by livestock and their access to the plants. Percent of tillers grazing was higher $(P<0.05)$ under the 10-day duration treatment than under the 2-day duration treatment (Table 5). This could reflect either more even distribution of grazing or the higher levels of forage intake as duration increased. More uniform utilization of pastures under longer grazing duration has been reported by Sheath (1983).

Grazing sheep are highly selective for green matter against dry (Arnold 1964; Thompson 1979; Guy and Watkin 1981) and for subclover over tall fescue in grass/clover mixtures (Bedell 1968). Sheep

Table 6. Relutive preference index (RPD) with $95 \%$ confidence interval (95\% CI) for tall fescue (Fear), subclover (Trsu) and others under 3 levels of grazing duration by sheep during early spring (April-May) and late spring (June-July) in 1988.

\begin{tabular}{|c|c|c|c|c|}
\hline $\begin{array}{l}\text { Forage } \\
\text { species }\end{array}$ & 2 & $\begin{array}{c}\text { Grazing druation } \\
\text { (days) } \\
6\end{array}$ & \multicolumn{2}{|l|}{10} \\
\hline \multicolumn{5}{|c|}{ Early Trial } \\
\hline & $95 \% \mathrm{CI}$ & $95 \% \mathrm{Cl}$ & $95 \% \mathrm{Cl}$ & $S E$ \\
\hline Fear & $0.78 \mathrm{a}(0.56-0.99)$ & $0.88 a(0.66-1.09)$ & $0.68 \mathrm{a}(0.46-0.88)$ & 0.06 \\
\hline Trsu & $0.64 \mathrm{a}(0.38-1.90)$ & $1.47 \mathrm{a}(1.21-1.73)$ & $1.53 \mathrm{a}(1.27-1.79)$ & 0.06 \\
\hline Others & $\begin{array}{l}1.06 a(0.71-1.41) \\
\text { Late trial } \\
\end{array}$ & $1.02 \mathrm{a}(0.67-1.37)$ & $1.11 \mathrm{a}(0.76-1.46)$ & 0.08 \\
\hline Fear & $0.86 \mathrm{a}(0.72-1.00)$ & $0.93 \mathrm{a}(0.79-1.07$ & $0.97 \mathrm{a}(0.83-1.11)$ & 0.03 \\
\hline Trsu & $1.67 \mathrm{a}(1.38-1.95)$ & $1.36 \mathrm{~b}(1.07-1.64)$ & $1.22 \mathrm{~b}(0.94-1.52)$ & 0.08 \\
\hline Others & $0.59 \mathrm{a}(0.38-0.81)$ & $0.83 \mathrm{a}(0.61-1.04)$ & $0.89 \mathrm{a}(0.67-1.10)$ & 0.07 \\
\hline
\end{tabular}

Means within a row not sharing a common letter differ $(P<0.05$, using Student-Newman Keuls test). SE is standard error. 
Table 7. Relative preference index (RPI) with $95 \%$ confidence interval (95\% CD) for tall fescue (Fear), subclover (Trsu) and others under 3 levels of grazing duration by sheep during early spring (April-May) and late spring (June-July) in 1989.

\begin{tabular}{|c|c|c|c|c|}
\hline $\begin{array}{l}\text { Forage } \\
\text { species }\end{array}$ & 2 & $\begin{array}{c}\text { Grazing druation } \\
\text { (days) } \\
6\end{array}$ & \multicolumn{2}{|l|}{10} \\
\hline \multicolumn{5}{|c|}{ Early trial } \\
\hline & $95 \% C I$ & $R P I \quad 95 \% C I$ & $95 \% C I$ & $S E$ \\
\hline Fear & $0.67 \mathrm{~b}(0.47-0.87)$ & $0.98 \mathrm{a}(0.78-1.18)$ & $1.08 \mathrm{a}(0.88-1.28)$ & 0.07 \\
\hline \multirow{2}{*}{$\begin{array}{l}\text { Trsu } \\
0.12\end{array}$} & $1.61 \mathrm{a}(1.27-1.95)$ & $1.10 \mathrm{~b}(0.77-1.43)$ & $0.91 \mathrm{~b}$ Others $(0.58$ & 1.24) \\
\hline & $1.25 \mathrm{a}(0.96-1.54)$ & $\begin{array}{l}0.87 \mathrm{ab}(0.58-1.16) \\
\text { Late trial } \\
\end{array}$ & $0.72 b(0.42-1.01)$ & 0.11 \\
\hline Fear & $0.86 \mathrm{~b}(0.72-0.92$ & $0.98 \mathrm{a}(0.88-1.08)$ & $1.02 \mathrm{a}(0.92-1.12)$ & 0.03 \\
\hline Trsu & $1.75 \mathrm{a}(1.42-2.07)$ & $1.13 b(0.81-1.44)$ & $1.15 b(0.83-1.47)$ & 0.12 \\
\hline Other & $1.29 \mathrm{a}(1.02-1.56)$ & $1.03 \mathrm{a}(0.76-1.30)$ & $0.87 b(0.60-1.14)$ & 0.08 \\
\hline
\end{tabular}

Means within a row not sharing a common letter differ $(P<0.05$, using Student-Newman Keuls test). SE is standard error.

in our 2-day duration treatments generally selected for subclover and against tall fescue (Tables 6 and 7). Selectivity for subclover was more pronounced in 2-day duration treatments than in 6 and 10-day duration during 3 out of our 4 trials. In the exception, early trial of 1988, subclover Relative Preference Indexes were also numerically higher for the 2-day compared to 10-day treatment, but differences lacked statistical significance. Tall fescue Relative Preference Indexes were lower on 2-day treatments compared to 6 and 10-day treatments in 1989. No treatment differences in tall fescue Relative Preference Indexes were evident in 1988

Although it was reported that short duration high density is a nonselective grazing system (Savory and Parsons 1980), our results suggest that sheep under 2-day grazing with high density were selective. High forage consumption under the 10-day duration treatment produced effectively higher grazing pressure under this treatment. Forage selectivity has been reported to decline as grazing pressure increases (Walker 1984).

\section{Management Implications}

It is generally assumed that high animal density for short grazing periods reduces dietary selectivity by grazing animals (Savory and Parsons 1980; Sharrow 1983) and results in more even and efficient utilization of forage produced (Hinnat and Kothmann 1986). Data in our study suggested that under very short duration ( 2 days), sheep grazed selectively, and forage utilization was less efficient and relatively uneven. Increasing duration to 10 days reduced dietary selectivity, increased grazing efficiency, and increased evenness of forage utilization by sheep. Clearly, the 2- day duration treatments do not appear to be a very attractive management option when one considers probable reduced livestock performance and higher labor cost to move animals more often. Furthermore, there was little advantage evident to using 6 vs 10 day rotation duration. In some studies, under longer duration/lower density grazing, grazing efficiency increases as animals are grouped together and move more rapidly from pasture to pasture (Hinnat and Kothmann, 1986; Malecheck and Dwyer 1983) In other studies, under very short duration/high density grazing, forage intake and grazing efficiency increased as the duration increased and density reduced (Sheath 1983; White and Cosgrove 1990). If one accepts both sets of observations, then our 10-day treatment may represent a lower limit below which grazing efficiency declines duration is further shortened and density is increased.

\section{Literature Cited}

Allison, C.D., and M.M. Kothmann. 1979. Effect of level of stocking pressure on forage intake and diet quality of range cattle. Proc. Western Sec. Amer... Soc. Anim. Sci. 30:174-178.

Allison, C.D., M.M. Kothmann, and L.R. Rittenhouse. 1982. Efficiency of forage harvest by grazing cattle. J. Range Manage. 35:351-354.

Arnold, G.W. 1964. Some principles in investigation of selective grazing. Proc. Aust. Soc. Anim. Prod. 5:258-271.

Arnold, G.W., and M.L Dudziniski. 1978. The Ethology of Free ranging Domestic Animals. Elsevier Scientific Publ. Amsterdam.

Bedell, T.E. 1968. Seasonal forage preferences of cattle and sheep in western Oregon. J. Range Manage. 21:291-297.

Guy, M.C., and B.R. Watkin. 1981. Effects of season, stocking rate, and grazing duration on diet selected by hoggots grazing mixed grass-subclover pastures. N.Z.J. Exp. Agr. 9:141-146.

Heitschmidt, R., and J. Walker. 1983. Short duration grazing and Savory grazing method in perspective. Rangelands 5:147-150.

Hinnant, R.T., and M.M. Kothmann. 1986. Frequency and intensity of defoliation under rotational grazing. Texas Agr. Exp. Sta. Prog. Rep. 4424. 1p.

Hobbs, N.T., and D.C. Bowden. 1982. Confidence interval on food preference indices. J. Wildl. Manage. 46:505-507.

Malechek, J.C., and D.D. Dwyer. 1983. Short-duration grazing double your livestock? Utah Sci. 44:32-37.

National Oceanic and Atmospheric Administration (NOAA), 1988 and 1989. Oregon Climatol. Data. Annual Summary. Dep. of Commerce, Nat. Climatic Center, Asheville, N.C.

Savory, A. , and S.D. Parsons. 1980. The Savory grazing method. Rangelands 2:234-237.

Sharrow, S.H. 1983. Forage standing crop and animal diets under rotational vs. continuous grazing. J. Range Manage. 36:447-450.

Sheath, G.W. 1983. Pasture utilization in hill country 1 . Influence of grazing duration and land contour. N.Z.J. Exp. Agr. 11:309-319.

Soil Conservation Service. 1975. Soil survey of Benton County area, Oregon. USDA, Washington, D.C.

Steel, R.G.O. ,and J. H. Torrie. 1980. Principles and procedures of statistics. Second edition. McGraw-Hill Book Company. New York, N.Y.

Stoltsz, C.W., and J.E. Dankwerts. 1990. Grass species selection pattern on rotationally-grazed Dohne Sourveld during autumn and early winter. J. Grassl. Soc. South Afr. 7:92-96.

Stuth, J.W., D.R. Kirhy, and R.E. Chemielewski. 1981. Effects of herbage allowance on the efficiency of defoliation by the grazing animal. Grass and Forage Sci. 36:9-15.

Thompson, N.A. 1979. Factor affecting animal production: Intake and utilization by ewes grazing grass/clover and lucerne pastures. Proc. N.C. Grassl. Assoc. 40:86-97.

Vallentine, J.F. 1990. Grazing Management . Academic Press Inc. N. Y. p. 553.

Van Dyne, G.M., and H.F. Heady. 1965. Botanical composition of sheep and cattle diets on a mature annual range. Hilgardia 36:465-465.

Walker, J.W. 1984. Grazing management theories and their application to short duration grazing. p. 176-179. In: Forage and Grassl. Conf., Houston. Tex. January 23-26.

White, J. G.H., and G.P. Cosgrove. 1990. Lucerne grazing management. 2. Effect of grazing duration on defoliation pattern by ewes. N.Z.J. Agr. Res. 33:621-625. 